\title{
KAJIAN DAN PELUANG PENELITIAN TATA KELOLA TEKNOLOGI INFORMASI: ULASAN LITERATUR
}

\author{
Nina Fadilah Najwa ${ }^{1}$, Tony Dwi Susanto² \\ ${ }^{1,2}$ Departemen Sistem Informasi, Fakultas Teknologi Informasi dan Komunikasi, Institut Teknologi Sepuluh \\ Nopember Surabaya \\ Email: ${ }^{1}$ nina.fadilah.najwa16@mhs.is.its.ac.id, ${ }^{1}$ tonydwisusanto@is.its.ac.id
}

(Naskah masuk: 27 Mei 2018, diterima untuk diterbitkan: 23 September 2018)

\begin{abstract}
Abstrak
Perkembangan transisi Teknologi Informasi (TI) saat ini menyebabkan penelitian terkait dengan tata kelola TI semakin meningkat.Tata kelola TI berperan besar dalam sebuah organisasi karena telah berubahnya peran dan relevansi TI dalam organisasi sehingga diperlukan pemahaman yang jelas terkait dengan tata kelola TI saat ini.Tujuan penulisan ulasanliteratur ini yaitu untuk mengulas perkembangan topik Tata Kelola dan peluang penelitian lebih lanjutterkait tata kelola TI sehingga dapat memberikan pemahaman tentang tata kelola TI. Metodologi yang digunakan pada ulasan literatur ini mencakup: 1) pendefinisian pertanyaan penelitian; 2) penetapan sumber literatur; 3) penentuan kata kunci pencarian literatur; 4) Pemilihan literatur; dan 5) ekstraksi data dan sintesis.Berdasarkan hasil ulasan literatur yang dilakukan, penelitian tata kelola TI secara luas diterapkan pada organisasi bisnis.Terdapat beberapa metode dan kombinasi dari beberapa metode yang digunakan dalam tata kelola TI, mencakup Control Objectives for Information and Related Technologies (COBIT), Information Technology Infrastructure Library (ITIL), Information Technology Balanced Scorecard (IT-BSC), dan metode-metode lain. Tren penelitianyang saat ini banyak dilakukan mencakup cloud computing governance, criteria success factor IT governance, penerapan dan atau evaluasi tata kelola dengan berbagai metode pada sektor bisnis, tata kelola TI pada universitas, peran tata kelola dalam pemerintahan dan rumah sakit. Peluang penelitian direkomendasikan berdasarkan future dan limitasi dari masing-masing paper yang dibahas.
\end{abstract}

Kata kunci: Kajian, Peluang Penelitian, Tata Kelola TI, Ulasan Literatur

\section{STUDY AND RESEARCH OPPORTUNITY OF INFORMATION TECHNOLOGY GOVERNANCE: A LITERATURE REVIEW}

\begin{abstract}
The development of the current Information Technology (IT) transition has led to more research on IT governance. IT governance plays a major role in an organization because it has changed the role and relevance of IT in the organization so that a clear understanding of current IT governance is needed. The purpose of this literature review is to review the development of Governance topics and further research opportunities related to IT governance so as to provide an understanding of IT governance. The methodology used in this literature review includes: 1) defining research questions; 2) determination of literature sources; 3) the determination of literature search keywords; 4) Selection of literature; and 5) data extraction and synthesis. Based on the results of the literature review conducted, IT governance research is widely applied to business organizations. There are several methods and combinations of several methods used in IT governance, including Control Objectives for Information and Related Technologies (COBIT), Information Technology Infrastructure Library (ITIL), Information Technology Balanced Scorecard (IT-BSC), and other methods. Current research trends include cloud computing governance, IT governance success factor criteria, governance implementation and or evaluation with various methods in the business sector, IT governance at universities, governance roles in government and hospitals. Research opportunities are recommended based on the future and limitations of each paper discussed.
\end{abstract}

Keywords: Study, IT Governance, Research Opportunities, Literature Review 


\section{PENDAHULUAN}

Transisi Teknologi Informasi (TI) terus berkembang dari yang dahulunya sebagai pendukung dalam transaksi (proses bisnis) hingga sekarang menjadi competitive advantage bagi organisasi(Mangalaraj, Singh, \& Taneja, 2014). TI menjadi aset yang kritis bagi organisasi dalam memenuhi perubahan dan perkembangan pasar untuk dapat bersaing. Perubahan peran dari TI bagi sebuah organisasi tentu membutuhkan berbagai macam pengelolaan struktur dan proses.

Tata kelola TI dapat menyediakan solusi yang baik untuk seluruh organisasi, seperti pemerintahan atau perusahaan privat dalam mengoptimalkan investasi TI dan practice serta menyeimbangkan risikonya(Alreemy, Chang, Walters, \& Wills, 2016). Tata kelola TI telah menjadi topik yang menarik karena pentingnya peran tata kelola TI tersebut dalam sebuah organisasi. Ketertarikan organisasi ataupun perusahaan terhadap tata kelola TI semakin berkembang karena telah berubahnya peran dan relevansi TI dalam organisasi, dan tentunya membutuhkan manajemen yang bagus(Lunardi, Becker, Maçada, \& Dolci, 2014). Berdasarkan hasil pengamatan dari sejumlah level organisasi bahwa kontribusi TI secara substansial berpengaruh pada pertumbuhan produktivitas organisasi. Kontribusi yang dimaksud adalah strategi TI yang selaras dengan strategi bisnis, sehingga TI dapat memberikan perubahan yang besar pada struktur organisasi, proses bisnis maupun aktivitas keseluruhan organisasi(Spremic \& D, 2008).

Tata kelola TI merupakan perkembangan dari corporate governance. Berdasarkan ITGI (2008) bahwa tata kelola TI bertujuan untuk memastikan efektivitas dari pemanfaatan TI dengan berfokus pada penyelarasan strategi (strategic alignment), manajemen risiko (risk management), manajemen sumber daya (resource management), value delivery dan pengukuran kinerja (performance measurement)(Spremic \& D, 2008),(Wilkin \& Chenhall, 2010). Komponen-komponen tersebut merupakan komponen tata kelola berdasarkan perspektif organisasi.

Dalam melakukan audit tata kelola TI terdapat berbagai standar yang bisa digunakan secara umum dan berbagai tipe organisasi (Putri, Aknuranda, \& Mahmudy, 2017). Salah satu standar tersebut adalah COBIT yang menyediakan kerangka kerja Tata Kelola TI (Mangalaraj et al., 2014). Ulasan literatur lainnya adalah mengenai literatur sistem informasi yang berkaitan dengan tata kelola dan bagaimana implementasinya pada bidang sistem informasi akunting. Ulasan ini berdasarkan taksonomi dari tata kelola dan mengumpulkan paper dari tahun 1998 hingga 2008 (496 paper) (Wilkin \& Chenhall, 2010). Selanjutnya terdapat ulasan literatur mengenai penerapan tata kelola TI pada bidang pendidikan tinggi (Kosala, 2017),(Yudatama, Nazief, Hidayanto, \& Mishbah, 2017). Kemudian, ulasan literatur mengenai dampak penerapan tata kelola TI saat post-implementation ERP (Wijaya, 2017) serta faktor kesuksesan kriteria penerapan tata kelola(Yudatama, Nazief, \& Hodayanto, 2017). Berdasarkan pencarian ulasan literatur yang serupa, belum adanya ulasan literatur secara general yang merepresentasikan perkembangan topik tata kelola TI pada berbagai bidang. Sehingga, ulasan literatur ini memberikan gambaran untuk peneliti selanjutnya untuk dapat melanjutkan penelitian berdasarkan rekomendasi dari ulasan ini.

Berdasarkan penjabaran diatas, maka terdapat dua pertanyaan penelitian (research question) yang akan diulas pada paper ini, yaitu: (1) Apa saja penelitian terkait tata kelola TI? (2)Bagaimana peluang penelitian untuk topik tata kelola TI berdasarkan hasil ulasan literatur?. Untuk menjawab kedua pertanyaan ini, akan dibahas lebih detail dan pencarian paper mengenai topik tata kelola TI.Pemilihan paper yang menjadi bahasan dalam paper ini melalui serangkaian langkah ataupun metodologi yang sistematis. Paper yang sudah dipilih tersebut di rangkum dan di analisis.Tujuan utama ulasan literatur ini adalah mengulas perkembangan topik dari tata kelola TI dan peluang penelitian untuk perlu di bahas lebih lanjut. Tujuan lainnya dari penulisan paperini adalah memberikan rangkuman terkait penelitian mengenai tata kelola TI sehingga diharapkan lebih mudah dipahami. Selain itu kontribusi yang diberikan oleh penulis yaitu melakukan mapping penelitian terdahulu dan mengklasifikasinnya menjadi beberapa tema untuk penelitian selanjutnya.

\section{TINJAUAN PUSTAKA}

\subsection{Tata Kelola TI}

Tata kelola TI merupakan tugas dari pemangku manajemen eksekutif untuk melakukan pengawasan dan mengimplementasikan strategi TI yang bertujuan untuk memastikan keselarasan antara TI dan bisnis, mengidentifikasi matriks untuk memastikan nilai bisnis dari TI dan untuk mengelola risiko TI dengan efektif(Spremic \& D, 2008). Tata kelola TI menjadi tanggungjawab utama untuk mengoptimalkan penggunaan sumber daya TI dan mengelola risiko dari proyek TI dan practice. Tata kelola dapat menyediakan solusi yang baik untuk seluruh organisasi, seperti pemerintahan atau perusahaan privat dalam mengoptimalkan investasi TI dan practice serta menyeimbangkan risikonya(Alreemy, Chang, Walters, \& Wills, 2016).

Tata kelola merupakan aksi, cara ataupun fakta dari megelola (mengontrol, meregulasi pengaruh atau pemesanan barang) dalam konsep enterprise. Tata kelola yang diaplikasikan pada enterprise menunjukkan bahwa tugas dari seorang direktur dalam mengelola, mengontrol, dan meregulasi enterprise mereka dengan best practices. Pada awalnya, istilah tata kelola muncul pada tahun 1993 
sebagai turunan dari corporate governance. Tata kelola berhubungan dengan tujuan strategis dan manajemen TI dari sebuah organisasi. Tata kelola TI menekankan pentingnya TI hubungannya dengan organisasi dan menyatakan bahwa keputusan strategis TI seharusnya menjadi pemikiran corporate board (komisaris) daripada manajer TI yang lain(Harmer, 2013).

Perbedaan antara manajemen TI dan tata kelola TI adalah pada fokus pengelolaannya. Manajemen TI berfokus pada efektifitas internal supply dari layanan dan produk TI. Sehingga, dapat disimpulkan manajemen TI mengurusi persoalan operasional TI. Sedangkan tata kelola mencakup lebih luas dan berfokus pada menunjukkan dan mentransformasikan TI untuk memenuhi kebutuhan sekarang dan kebutuhan masa depan (internal) dan pelanggan (eksternal) (Van Grembergen et al., 2004) dalam (Lunardi et al., 2014).

\subsection{Taksonomi Tata Kelola TI}

Tata kelola TI juga mencakup keseluruhan aspek organisasi yang berkaitan dengan penerapan TI seperti mendefinisikan kebijakaan, keputusan menggunakan TI (hak dan tanggungjawab), persetujuan investasi dan proyek, pemeliharaan dan monitoring keseluruhan TI, dan evaluasi dari IT value delivery, dan sebagainya (Lunardi et al., 2014). Cakupan tata kelola TI merupakan topik yang memiliki ruang lingkup yang luas, yang berkaitan dengan berikut ini (Spremic \& D, 2008), (Wilkin \& Chenhall, 2010):

1. Penyelarasan strategi (strategic alignment)

2. Manajemen risiko (risk management)

3. Manajemen sumber daya (resource management)

4. Value delivery

5. Pengukuran kinerja (performance measurement).

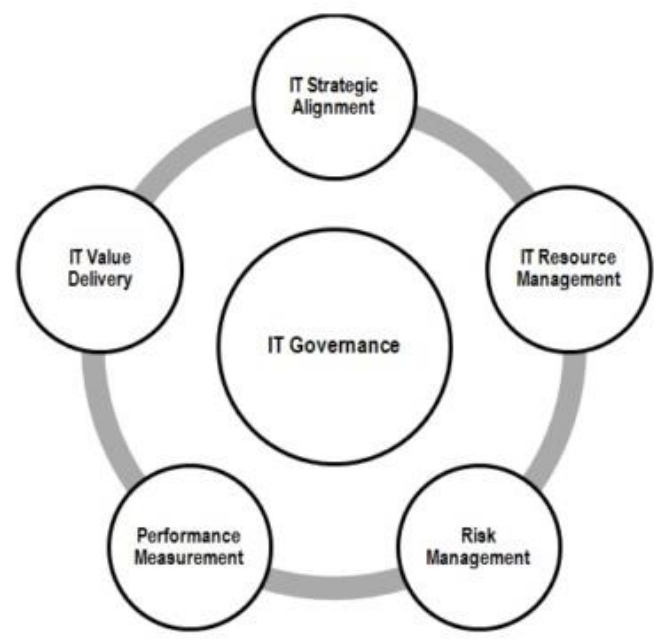

Gambar 1. Perspektif Organisasi dari interaksi komponen ITG(Sumber:(Yudatama, Nazief, \& Hodayanto, 2017))
Keterkaitan antara kelima komponen tersebut dalam tata kelola TI dapat dilihat sebagaimana pada Gambar 1. Tata Kelola TI mengelola kelima komponen tersebut dalam sebuah organisasi.

\subsection{Metode/Kerangka Kerja Tata Kelola}

Berdasarkan taksonomi tata kelola terdapat 5 komponen tata kelola yang juga memiliki berbagai metode dalam penggunaannya(Spremic \& D, 2008),(Wilkin \& Chenhall, 2010). Tata kelola TI mencakup manajemen risiko, keamanan informasi, kualitas layanan, manajemen sumber daya TI, dan bisnis/TI alignment. Pada dasarnya, manajemen risiko dan keamanan informasi berkaitan erat (kombinasi) dan dalam tata kelola dikenal sebagai Information Security Governance (ISG).

Adapun kerangka kerja terkait dengan tata kelola seperti ISO/IEC 38500, ISO/IEC 27001, COBIT, dan ITIL(Jairak \& Praneetpolgrang, 2013). ISO/IEC 38500 merupakan standar untuk hirarki pembuat keputusan (Decision making hierarchy), ISO 27001 dan BS25999 untuk standar manajemen risiko dan keamanan informasi, CMM dan balanced scorecard untuk kerangka kerja manajemen kinerja, PMBOK dan PRINCE2 untuk manajemen proyek, ITIL untuk manajemen layanan TI, dan Value IT untuk value delivery(Alreemy et al., 2016). Diantara banyaknya kerangka kerja yang ada, COBIT merupakan kerangka kerja yang banyak digunakan dalam tata kelola TI. Saat ini, COBIT versi 5.0 telah memberikan kemudahan dalam penerapan tata kelola TI dengan mengintegrasikan berbagai kerangka kerja yang ada (Jairak \& Praneetpolgrang, 2013).

\subsection{Penelitian Terdahulu}

Ulasan literatur oleh (Mangalaraj et al., 2014) yang mengulas tentang COBIT sebagai kerangka kerja dari tata kelola TI. Ulasan literatur lainnya adalah mengenai literatur sistem informasi yang berkaitan dengan tata kelola dan bagaimana implementasinya pada bidang sistem informasi akunting. Ulasan ini berdasarkan taksonomi dari tata kelola dan mengumpulkan paper dari tahun 1998 hingga 2008 (496 paper) (Wilkin \& Chenhall, 2010). Ulasan literatur mengenai penerapan tata kelola TI pada bidang pendidikan tinggi (Kosala, 2017),(Yudatama, Nazief, Hidayanto, et al., 2017). Ulasan literatur mengenai dampak penerapan tata kelola TI saat post-implementation ERP (Wijaya, 2017) serta faktor kesuksesan kriteria penerapan tata kelola (Yudatama, Nazief, \& Hodayanto, 2017). Berdasarkan pencarian ulasan literatur yang serupa, belum adanya ulasan literatur secara general yang merepresentasikan perkembangan topik tata kelola TI pada berbagai bidang. Sehingga, ulasan literatur ini memberikan gambaran untuk peneliti selanjutnya untuk dapat melanjutkan penelitian berdasarkan rekomendasi peluang penelitian. 


\section{METODOLOGI PENELITIAN}

Pada tahapan ini mendeskripsikan metodologi dalam mengulas literatur berdasarkan panduan dari Kitchenham (2007). Dasar dari melakukan ulasan literatur ini adalah untuk mengumpulkan dan mengevaluasi seluruh penelitian yang berhubungan dengan pertanyaan yang diangkat untuk dibahas, kemudian menghasilkan ketidakbiasan, dan teruji. Tujuan dari literatur review ini menurut Kitchenham, adalah untuk mengidentifikasi, mengevaluasi, dan penelitian yang tersedia terkait dengan pertanyaan pada penelitian atau topik, atau fenomena yang menarik (Kitchenham, 2007).

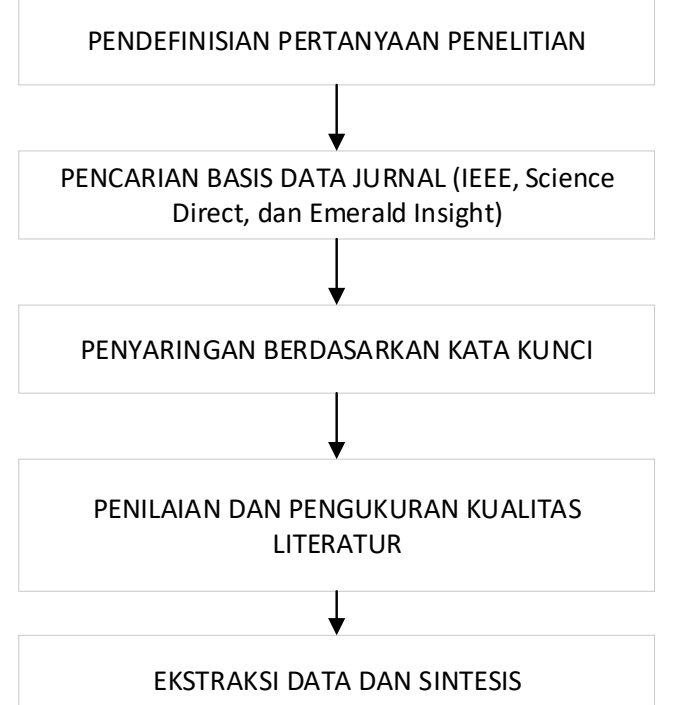

Gambar 2. Metologi yang Digunakan pada Ulasan Literatur

Metodologi yang penulis gunakan dalam ulasan literatur dari paper dan jurnal seperti yang disajikan pada Gambar 2 mencakup: 1) pendefinisian pertanyaan penelitian (research question); 2) penetapan sumber literatur; 3) penentuan kata kunci pencarian literatur; 4) Pemilihan literatur; dan 5) mengekstrasi data dan melakukan sintesis. Masing-masing tahapan dijelaskan pada subbab selanjutnya.

\subsection{Pertanyaan Penelitian (Research Question)}

Spesifikasiulasan literatur dilakukan dengan merumuskan pertanyaan penelitian (research question), yaitu:

1. RQ1 :Apa saja penelitian terkaittata kelola TI?

2. RQ2 : Bagaimana peluang penelitian untuk topik tata kelola TI berdasarkan hasil ulasan literatur?

\subsection{Sumber literatur}

Untuk memperoleh ulasan literatur dengan kualitas yang baik, maka sumber literatur yang digunakan untuk pencarian literatur dibatasi hanya pada situssitus penyedia jurnal internasional terkemuka, yaitu :
1. Science direct (www.sciencedirect.com)

2. IEEE (ieeexplore.ieee.org)

3. Emerald (emeraldinsight.com)

\subsection{Kata Kunci Pencarian Literatur}

Berikut kata kunci yang digunakan untuk melakukan pencarian literatur yang terkait mencakup beberapa kata kunci "IT Governance" dan "Information Technology Governance".

\subsection{Penilaian Literature}

Penilaian literatur dilakukan berdasarkan kriteria inclusion dan exclusion sebagai pemilihan paper yang akan dibahas:

Kriteria Inclusion:

1. Isi Paper sesuai dengan yang akan dibahas dengan membaca abstrak penelitian.

2. Tahun publikasi paper yang dibahas minimal tahun 2013.

3. Paper yang dibahas berupa jurnal atau conferences.

4. Paper yang digunakan menggunakan bahasa pengantar yaitu bahasa inggris.

5. Termasuk dalam kriteria topik (information system, information system management, dan information technology).

6. Pencarian literatur pada situs-situs penyedia jurnal internasional yang telah ditentukan sebelumnya.

7. Judul terdapat kata IT Governance, Information Technology Governance, Information Governance.

Kriteria Exclusion:

1. Topik tidak berhubungan dengan pembahasan IT Governance, dan tidak mencakup pertanyaan penelitian.

2. Bahasa pengantar paper bukan berbahasa inggris.

3. Selain jurnal dan conferences dengan tahun terbit dibawah tahun 2013.

\subsection{Pengukuran Kualitas (Quality Assessment)}

Klasifikasi paper yang telah diperoleh berdasarkan pengukuran kualitas. Pengukuran kualitas berdasarkan hal sebagai berikut:

1. Penelitian termasuk dalam bidang Tata Kelola TI.

2. Metode yang digunakan dalam penelitian tata kelola TI (COBIT, ITIL, dan sebagainya).

3. Termasuk ke dalam tipe penelitian: Survey/ Questionnaire-based research dan Non Questionnaire-based research.

4. Field study meliputi bidang penelitian yang menjadi objek pada paper. Seperti bidang pemerintahan, perusahaan profit, dsb.

5. Temuan yang didapatkan dari penelitian. 
6. Limitasi yang dapat menjadi peluang pada penelitian selanjutnya.

\subsection{Ekstraksi Data dan Sintesis}

Ekstraksi data untuk memperoleh informasi yang akurat dan konsisten. Adapun data yang termasuk dalam ekstraksi adalah identifikasi, nama penulis, tahun publikasi, sumber, referensi, metodologi pengumpulan data, analisis data sertakonsep. Adapun pencarian paper tambahan juga didapatkan dari referensi dari main paper yang menjadi landasan ide dari pembuatan review literatur ini. Sintesis dilakukan berdasarkan pengelompokkan tema paper yang didapatkan untuk dapat memetakan penelitian terkait IT Governance yang telah ditemukan.

\section{HASIL DAN PEMBAHASAN}

\subsection{RQ1. Apa saja penelitian terkait tata kelola TI?}

Telah ada beberapa literatur yang mengulas mengenai tata kelola (Mangalaraj et al., 2014), (Wilkin \& Chenhall, 2010), (Kosala, 2017),(Yudatama, Nazief, Hidayanto, et al., 2017), (Wijaya, 2017), (Yudatama, Nazief, \& Hodayanto, 2017). Berdasarkan pencarian ulasan literatur yang serupa, belum adanya ulasan literatur secara general yang merepresentasikan perkembangan topik tata kelola TI pada berbagai bidang. Sehingga, ulasan literatur ini memberikan gambaran untuk peneliti selanjutnya untuk dapat melanjutkan penelitian berdasarkan rekomendasi dari ulasan ini.

Literatur yang dibahas merupakan literatur yang terbit dalam rentang tahun 2013 hingga tahun 2017 dan dipilih berdasarkan kriteria inclusion yang telah didefinisikan pada metodologi ulasan literatur. Pada Tabel 1 hasil dari pengumpulan jurnal dari setiap tahunnya paling banyak terdapat pada emerald dibandingkan IEEE dan sciencedirect.

\begin{tabular}{cccc}
\multicolumn{4}{c}{ Tabel 1. Hasil Pengumpulan Literatur } \\
\hline Tahun & IEEE & $\begin{array}{c}\text { Science } \\
\text { Direct }\end{array}$ & Emerald \\
\hline 2013 & 127 & 2365 & 3140 \\
2014 & 150 & 2875 & 3743 \\
2015 & 126 & 3271 & 3827 \\
2016 & 154 & 3602 & 2319 \\
2017 & 161 & 4062 & 2554 \\
\hline Total & 718 & 16175 & 15583 \\
\hline
\end{tabular}

Berdasarkan hasil pencarian dengan menggunakan kata kunci yang telah dilakukan, sciencedirect memiliki paling banyak jumlah paper yang berhubungan dengan kata kunci. Pada basis data IEEE dan Sciencedirect setiap tahunnya mengalami kenaikan dalam topik governance. Sedangkan pada basis data Emerald, mengalami penurunan semenjak tahun 2016 seperti yang ditunjukkan pada Gambar 3 berikut ini.

\section{Hasil Pencarian}

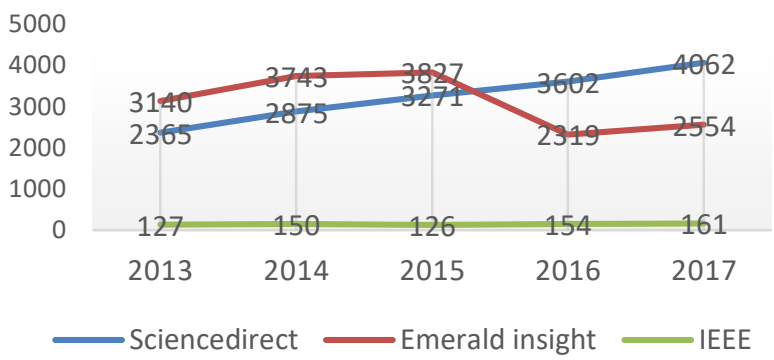

Gambar 3. Hasil penyaringan literatur

Berdasarkan hasil pencarian literatur yang telah dilakukan, pada akhirnya terdapat 34 paper yang menjadi acuan untuk ulasan literatur ini. Pemilihan literatur dilakukan berdasarkan kriteria inclusion dan exclusion yang telah di tentukan sebelumnya. Pada Tabel 2 dapat dilihat jumlah paper yang telah diseleksi untuk di ulas.

Tabel 2. Hasil Berdasarkan Kriteria Inclusion dan exclusion

\begin{tabular}{ccc}
\hline Basis Data & $\begin{array}{c}\text { Jumlah } \\
\text { Pencarian }\end{array}$ & Seleksi Akhir \\
\hline IEEE & 718 & 10 \\
Science Direct & 16175 & 19 \\
Emerald & 15583 & 2 \\
Paper relevan & - & 3 \\
\hline
\end{tabular}

Paper yang menjadi acuan setelah melewati tahapan seleksi, kemudian dilakukan pengukuran kualitas dan melakukan klasifikasi paper tersebut berdasarkan bidang penelitian, metode tata kelola yang digunakan, serta tipe penelitian yang digunakan.

Berdasarkan tipe penelitian yaitu penelitian yang berbasis survey atau kuisioner dan penelitian yang tidak menggunakan kuisioner. Berdasarkan klasifikasi, pada Gambar 4. dapat dilihat bahwa penelitian yang diulas lebih banyak yang berbasis survey/questionnaire based yaitu berjumlah 19 penelitian, sedangkan sisanya yaitu 15 penelitian berbasis non questionnaire.

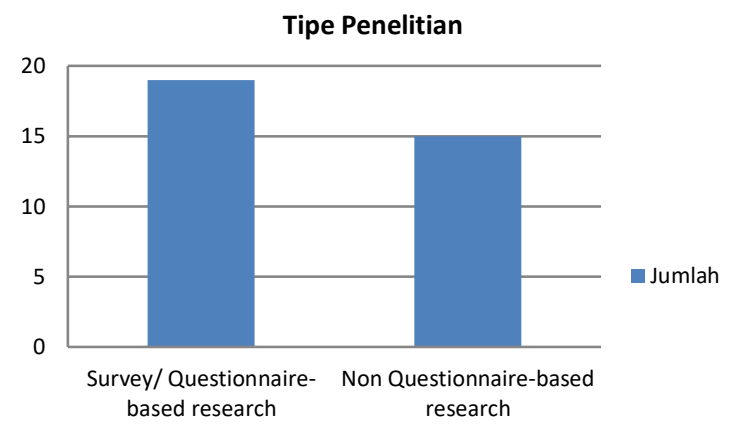

Gambar 4. Klasifikasi berdasarkan tipe penelitian 
Berdasarkan field of study, dapat dilihat pada Gambar 5, bahwa pembahasan tata kelola TI secara luas diterapkan pada organisasi bisnis. Kemudian, pembahasan tata kelola TI juga dibahas pada sektor pendidikan terutama pada tingkat universitas. Tata kelola TI juga dibahas pada sektor pemerintahan, rumah sakit, cloud computing dan penggunaan tata kelola TI oleh pakar/praktisi TI.

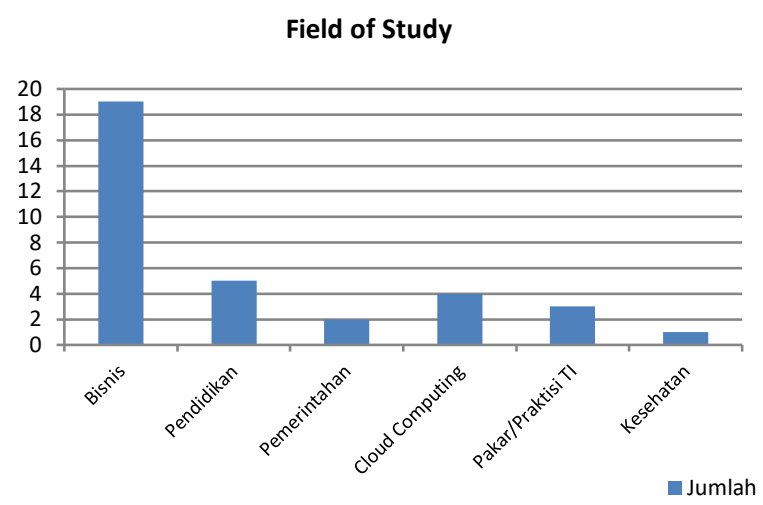

Gambar 5. Klasifikasi berdasarkan Field of Study

Berdasarkan metode ataupun konseptual model yang dikembangkan dari topik penelitian tata kelola TI dapat dilihat pada Tabel 3. Penelitian terdahulu menggunakan berbagai macam metode dan kombinasi dari beberapa metode dalam melakukan penelitian di bidang tata kelola TI. Paling banyak ditemukan penggunaan metode COBIT. Selain itu, metode kombinasi antara COBIT, ITIL, ITBSC, SCRUM, VAL IT, dan sebagainya telah dikategorisasikan berdasarkan penelitinya pada Tabel 3. Hasil klasifikasi dari ketiga kategori yang telah dijabarkan, selanjutnya dikelompokkan menjadi beberapa tema sebagai rekomendasi tema untuk penelitian selanjutnya seperti pada Tabel 4 .

Tabel 4. Kategorisasi Tema Penilitian

\begin{tabular}{l} 
Tema \\
\hline Cloud Computing \\
Governance \\
\\
Criteria Success \\
Factor IT Governance \\
Penerapan, dan atau \\
evaluasi tata kelola \\
dengan berbagai \\
metode (COBIT dan \\
Kombinasi Metode \\
Lainnya, konseptual \\
model) pada sektor \\
bisnis
\end{tabular}

(Suicimezov \& Georgescu, 2014),

(Prasad, Green, \& Heales, 2014),(Prasad \& Green, 2015),(Rebollo, Mellado,

Fernández-Medina, \& Mouratidis, 2015) (Alreemy et al., 2016),

(Li, Chang, \& Yen, 2017)

(Aguillar, Murakami, Junior, \& Jr., 2017), (Ibrahim \& Nurpulaela, 2017),(Kosasi, Vedyanto, \& Yuliani, 2017), (Lin \& Wittmer, 2017), (Park, Lee, Daniel Lee, \& Koo, 2017), (Sandfreni \& Adikara, 2017), (Guetat \& Dakhli, 2015),(Bermejo, Tonelli, Zambalde, Santos, \& Zuppo, 2014),(Nuroğlu, 2016), (Wilkin, Couchman, Sohal, \& Zutshi, 2016), (Thompson, Ekman, Selby, \& Whitaker, 2014), (Fazlida \& Said, 2015), (Ali, Green, \& Robb, 2015), (Chi, Zhao, George, Li, \& Zhai, 2017), (Smits \& Van Hillegersberg, 2017), (Lunardi et al., 2014), (Bin-Abbas \& Bakry, 2014), (Joshi, Bollen, Hassink, De Haes, \& Van Grembergen, 2018), (Sirisomboonsuk, Gu, Cao, \& Burns,

\begin{tabular}{ll}
\hline \multicolumn{1}{c}{ Tema } & \multicolumn{1}{c}{ Peneliti } \\
\hline & 2018), (Kerr \& Murthy, 2013) \\
Tata Kelola TI pada & (Kosasi, 2017),(Jairak, Praneetpolgrang, \\
\&niversitas & $\begin{array}{l}\text { Praneetpolgrang, 2013), (Juiz, Gómez, } \\
\text { \& Barceló, 2012),(Bianchi, Sousa, }\end{array}$ \\
& $\begin{array}{l}\text { Pereira, \& Luciano, 2017) } \\
\text { (Ekanata \& Girsang, 2015),(Lapihu \& }\end{array}$ \\
Peran Tata kelola & Isnanto, 2017),(Shalannanda \& Hakimi, \\
$\begin{array}{l}\text { dalam Pemerintahan } \\
\text { dan rumah sakit } \\
\text { (publik) }\end{array}$ & 2016) \\
\hline
\end{tabular}

\subsection{RQ2. Bagaimana peluang penelitian untuk topik tata kelola TI berdasarkan hasil ulasan literatur?}

Paper yang telah diulas memiliki limitasi penelitian dan rekomendasi untuk penelitian selanjutnya. Paper-paper tersebut disintesis menjadi beberapa tema. Tema menggambarkan beberapa peluang penelitian dalam topik tata kelola TI. Hal ini dilakukan agar mempermudah dalam memahami alur penelitian yang menjadi peluang untuk diteliti. Pada Tabel 4 dapat dilihat terdapat lima tema dengan nama peneliti yang tercakup didalamnya. Sehingga, peluang penelitian secara umum dapat di lihat pada Tabel 5. Penjelasan secara lebih detail mengenai masing-masing penelitian yang tercakup di dalam tema dijelaskan pada BAB 5 (Diskusi).

\section{DISKUSI}

\subsection{Tema 1: Cloud Computing Governance}

Cloud Computing adalah sebuah paradigma yang berkembang untuk mendukung cara-cara efisien yang disediakan oleh layanan IT untuk memenuhi kebutuhan layanan dan kemudahan dalam mengakses sumber daya. Jika perusahaan enterprise ingin memperoleh manfaat dari penggunaan cloud computing, sebuah strategi tata kelola dan perencanaan manajemen harus dibangun dengan jelas(ISACA, 2013).

Penelitian yang dilakukan oleh (Suicimezov \& Georgescu, 2014) berfokus pada keamanan cloud computing pada level bisnis, dan memberikan presentasi terhadap kerangka kerja security governance cloud framework. Kerangka kerja tata kelola pada cloud merupakan sesuatu yang penting. Hal ini dikarenakan keamanan secara tradisional tidak efektif dan tidak sesuai dengan cloud computing. Sehingga, dengan adanya usulan kerangka kerja tata kelola cloud ini dapat menerapkan kerangka kerja tersebut berdasarkan beberapa peraturan dasar tetapi yang paling penting adalah kerangka ini dapat eksis selama cloud digunakan dalam skala banyak.

Usulan kerangka kerja tata kelola keamanan cloud computing juga di teliti oleh (Rebollo et al., 2015). Kontribusi dari penelitian ini adalah menyediakan kerangka kerja tata kelola keamanan cloud computing dengan mengujinya pada studi kasus, kemudian mendemonstrasikan 
kebermanfaatan dan dampak dari kerangka kerja tersebut pada organisasi. Untuk penelitian selanjutnya, diharapkan dapat fokus pada peningkatan kerangka kerja, dan menguji kerangka kerja yang diajukan pada studi kasus lainnya.

Penelitian yang dilakukan oleh (Prasad et al., 2014) mengadopsi pendekatan triangulasi dan memberikan 4 saran struktur tata kelola cloud yang mungkin dapat diterapkan. Struktur ini berhubungan dengan layanan cloud computing, pentingnya memiliki orang yang ahli dalam bidang cloud, kebijakan cloud serta manajemen dan integrasi layanan cloud computing dalam sebuah organisasi. Penelitian ini juga memberikan perspektif organisasi terkait struktur tata kelola yang berhubungan secara langsung dengan tujuan organisasi dan secara tidak langsug berhubungan dengan keuangan organisasi. Untuk penelitian selanjutnya adalah dengan

Tabel 3. Hasil Berdasarkan Metode/Kerangka Konseptual

\begin{tabular}{|c|c|c|}
\hline & Metode/Konseptual & $\begin{array}{ll} & \text { Peneliti } \\
\end{array}$ \\
\hline 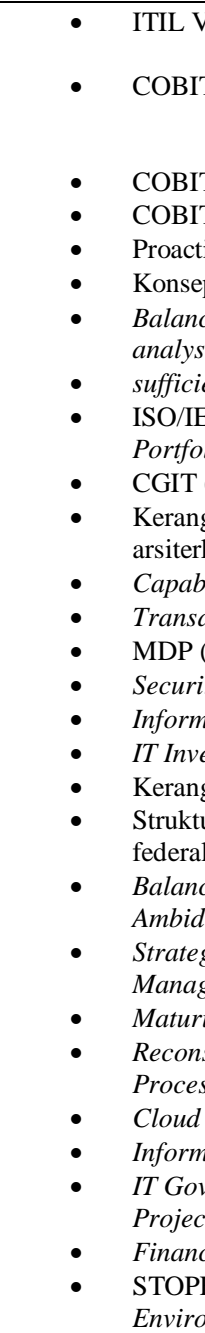 & $\begin{array}{l}\text {. ITBSC } \\
.0, \text { ABNT NBR ISO/IEC 12207, PDCA, SCRUM } \\
\text { Information Security Behavior (PISB) } \\
\text { lal model: Extended Resource-Based View(ERBV) } \\
\text { l scorecard metrics dan importance-performance } \\
\text { cy economy philosophy (SEP), ISO/IEC } 38500 \\
\text { 38500, Bussiness/IT Alignment melalui Project } \\
\text { Approval Process } \\
\text { RINCE2, ITIL, COBIT, Val IT, ISO /IEC } 38500) \\
\text { aKerja Tata kelolainformasi yang } \\
\text { InInformasiterdiridari } 4 \text { pilar dan } 4 \text { aksi. } \\
\text { ty Maturity Model (CMMI) } \\
\text { ion Costs, Resource-Based View, IT Capability } \\
\text { arkov Decision Process) Model } \\
\text { Governance Framework } \\
\text { ion Security Governance } \\
\text { ment Governance (ITIG), Val IT } 2.0 \\
\text { akerjaSuccess Factors for IT Governance (SFITG) } \\
\text { T Governance (sentralisasi, desentralisasi, dan } \\
\text { g Governance, Complementing Governance, IT } \\
\text { terity, Relational Performance } \\
\text { Alignment, Risk Management, Resource } \\
\text { nent } \\
\text { IT Governance (MIG) } \\
\text { leration of IT Governance Structure, Business } \\
\text { Performance, Overall firm Performance } \\
\text { overnance Structure } \\
\text { ion Security Governance (ISG) Cloud } \\
\text { Pent }\end{array}$ & 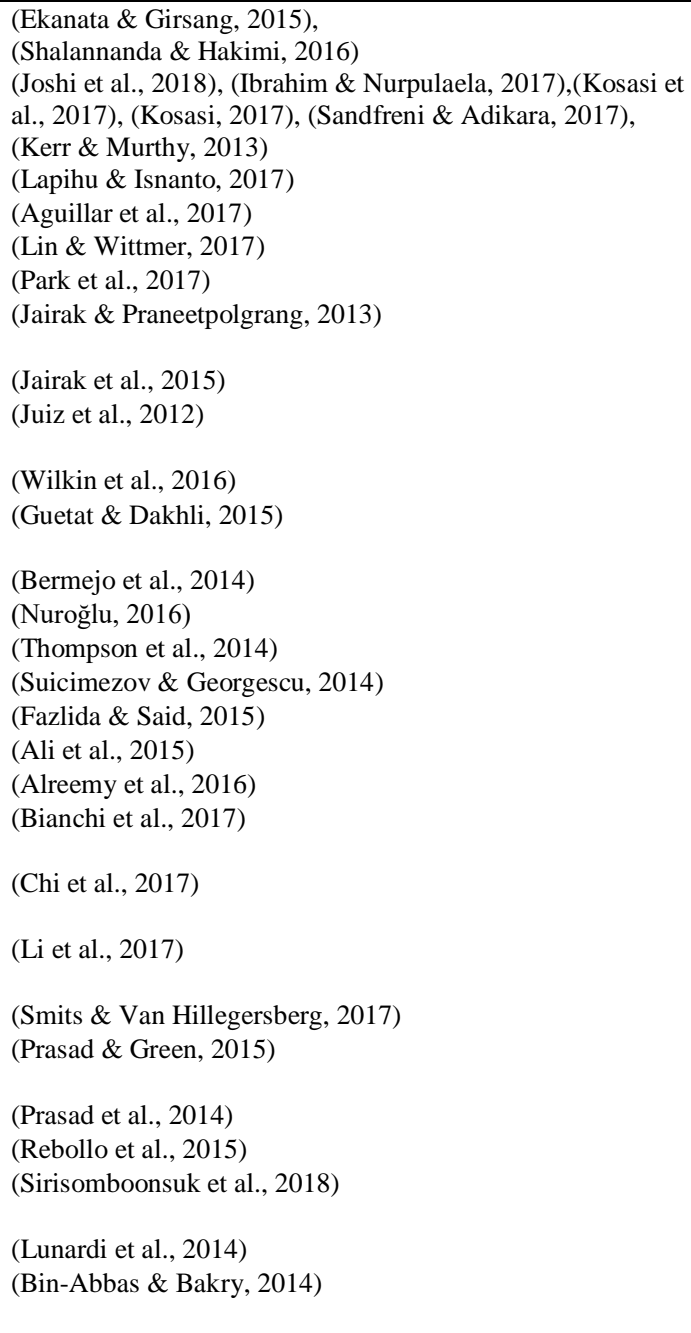 \\
\hline \multicolumn{3}{|c|}{ Tabel 5. Peluang Penilitian } \\
\hline $\begin{array}{l}\text { Cloud } \\
\text { Computing } \\
\text { Governance } \\
\end{array}$ & $\begin{array}{ll}\text { - } & \text { Tata Kelola Keamanan cloud computing } \\
\text { - } & \text { Keefektifan struktur tata kelola untuk layanan } c \\
\text { - } & \text { Membangun dataset yang spesifik untuk pengad } \\
\end{array}$ & $\begin{array}{l}\text { computing } \\
\text { layanan cloud computing }\end{array}$ \\
\hline $\begin{array}{l}\text { Criteria Success } \\
\text { Factor IT } \\
\text { Governance }\end{array}$ & $\begin{array}{l}\text { - Menguji Kerangka Kerja SFITG } \\
\text { - Observasi CSF untuk sistem ERP dengan drives } \\
\text { kelola TI. }\end{array}$ & kelola TI secara positif memberi dampak pada hasil tata \\
\hline $\begin{array}{l}\text { Penerapan, dan } \\
\text { atau evaluasi tata } \\
\text { kelola dengan } \\
\text { berbagai metode } \\
\text { (COBIT dan } \\
\text { Kombinasi } \\
\text { Metode Lainnya, } \\
\text { konseptual } \\
\text { model) pada } \\
\text { sektor bisnis }\end{array}$ & $\begin{array}{l}\text { - Implementasi COBIT pada perusahaan kecil der } \\
\text { - Penelitian yang longitudinal / Pengukuran secar } \\
\text { - Mengukur dampak dari tingginya kematangan t: } \\
\text { - Peningkatan proses hingga ke level } 3 \text { dengan me } \\
\text { - Observasi keterlibatan organisasi yang lebih ke } \\
\text { - yang sebanding dengan rekan bisnis yang lebih } \\
\text { - Menguji coba dan mengeksplorasi model konse } \\
\text { - Penerapan Information Security Governance fra } \\
\text { - Observasi hubungan internal market dan hierark } \\
\text { - Menguji coba/investigasi dampak TI pada bu: }\end{array}$ & $\begin{array}{l}\text { In seperangkat kontrol dan proses. } \\
\text { erkala nilai tingkat kematangan dengan domain lainnya. } \\
\text { kelola TI pada nilai perusahaan } \\
\text { kukan perbaikan langkah dalam BAI04 pada studi kasus. } \\
1 \text { dengan CGIT untuk menghasilkan nilai bisnis dengan cara } \\
\text { sar. } \\
\text { lalPISB pada studi kasus lainnya } \\
\text { ework } \\
\text { eksternal tata kelolaterhadap kinerja perusahaan. } \\
\text { ess network, dengan variabel Transaction Costs, Resource- }\end{array}$ \\
\hline
\end{tabular}




\begin{tabular}{|c|c|}
\hline Tema & Peluang Penelitian \\
\hline & $\begin{array}{l}\text { Based View, IT Capability. } \\
\text { - Validasi kerangka kerja(Guetat \& Dakhli, 2015) } \\
\text { - Mengaplikasikan instrumen penelitian pada negara lainnya (Bermejo et al., 2014) } \\
\text { - } \text { Implementasi dan validasi eksternal Markov Decision Process } \\
\text { - Menambahkan dimensi baru untuk instrumen ITIG. } \\
\text { - Menguji hubungan keterkaitan antara ITIG dan IT-enabled proses bisnis } \\
\text { - } \text { Mengidentifikasi faktor sebab dan akibat yang berhubungan dengan tingkat ITIG dalam organisasi. } \\
\text { - Menginvestigasi antecendents dari kedua strategi tata kelola. Menguji konseptual pada studi kasus lain(Chi et } \\
\text { al., 2017) } \\
\text { - Eksplorasi kinerja perusahaan pada situasi yang berbeda dengan mengkombinasikan balancing dan } \\
\text { complementing tata kelola. } \\
\text { - Menguji kombinasi dari elemen kunci dari Maturity IT Governance(MIG) model (Hard and soft } \\
\text { governance)dan melakukan validasinya. } \\
\text { - Mengidentifikasi manfaat langsung maupun tidak langsung dengan mekanisme tata kelola. Menunjukkan } \\
\text { dampaknya pada proses bisnis dan keseluruhan kinerja } 1 \text { tahun setelah pengimplementasian. } \\
\text { - Menguji model konseptual penelitian (Sirisomboonsuk et al., 2018). } \\
\text { - Menambahkan sejumlah elemen kontrol yang diperlukan pada model STOPE. }\end{array}$ \\
\hline $\begin{array}{l}\text { Tata Kelola TI } \\
\text { pada Universitas }\end{array}$ & $\begin{array}{l}\text { - Uji coba pada universitas lainnya tata kelola TI berdasarkan SEP dengan ISO/IEC } 38500 \text { dan membuktikan } \\
\text { regulasi yang diusulkan. } \\
\text { - memvalidasi impelementasi tata kelola TI pada universitas berdasarkan ISO/IEC 38500, Bussiness/IT } \\
\text { Alignment melalui Project Portfolio Approval Process melalui survey. } \\
\text { - Mengumpulkan data dari lebih banyak universitas untuk meningkatkan pemahaman tentang struktur tata kelola } \\
\text { TI yang diadopsi. }\end{array}$ \\
\hline $\begin{array}{l}\text { Peran Tata kelola } \\
\text { dalam } \\
\text { Pemerintahan } \\
\text { dan rumah sakit } \\
\text { (publik) }\end{array}$ & - Implementasi tata kelola TI pada sektor publik lainnya. \\
\hline
\end{tabular}

memperhatikan keefektifan dari struktur tata kelola ini untuk layanan cloud computing dalam berbagai sektor organisasi ataupun mempertimbangkan struktur lainnya yang mungkin lebih cocok untuk layanan cloud computing tertentu.

Selanjutnya, penelitian lanjutan dari struktur tata kelola cloud yang dilakukan oleh (Prasad \& Green, 2015)menggunakan metode data survey menemukan keterkaitan positif antara tata kelola consideration dan kinerja proses bisnis. Kemudian, membuktikan hubungan positif antara kinerja proses bisnis dan keseluruhan kinerja perusahaan. Berdasarkan hasil tersebut pertimbangan yang disarankan pada struktur tata kelola dapat berkontribusi pada layanan cloud computing-related IT-business alignment dan menyebabkan antisipasi nilai bisnis dari layanan cloud computing. Penelitian ini juga memberikan panduan bagi organisasi terkait persyaratan yang diperlukan untuk menjaga nilai bisnis layanan cloud computing. Penelitian selanjutnya dapat membangun dataset yang spesifik untuk pengadopsi layanan cloud computing sebagai penguatan hasil dari penelitian ini, dan meningkatkan validitas internal dengan memperhatikan orang kunci dalam organisasi/perusahaan. Hal ini dikarenakan untuk mendapatkan hasil yang lebih objektif dari bisnis proses dan keseluruhan kinerja perusahaan.

\subsection{Tema 2: Criteria Success Factor IT Governance}

Pengimplementasian tata kelola perlu memperhatikan CSF. Perumusan kerangka kerja tata kelola TI dengan mempertimbangkan CSF dilakukan oleh (Alreemy et al., 2016). Kerangka kerja yang diberi nama Kerangka kerja Success Factors for IT Governance (SFITG) telah divalidasi melalui kuisioner dan survey online oleh 100 pakar dari global (berbagai negara maju maupun negara berkembang seperti UK, US, Australia dan Malaysia). Validasi juga dilakukan kepada pakar budaya sebanyak 120 pakar. Penelian selanjutnya diharapkan dapat menguji kerangka kerja yang diajukan pada studi kasus.

Penelitian lainnya dilakukan oleh ( $\mathrm{Li}$ et al., 2017)menunjukkan bahwa kebutuhan akan manajemen risiko dan manajemen sumber daya masih belum diperhitungkan. Driver dari manajemen risiko lebih tidak aktif dibandingkan manajemen sumber daya dan penyelarasan strategi. Hanya beberapa penelitian yang menyediakan panduan bagi manajer tentang bagaimana mengutilisasi keterbatasan sumber daya yang dimiliki setelah post implementation. Sehingga, penelitian ini memberikan CSFs untuk sistem ERP sebagai penelitian yang dapat mendemonstrasikan pencapaian kualitas yang tinggi dari tata kelola TI.

Kegagalan CSF untuk sistem ERP dengan melihat interdependensi antara fase dan hubungan antara driver dan hasil tata kelola TI. Observasi ini dapat dieksplorasi dalam pada penelitian selanjutnya. Penelitian selanjutnya dapat memverifikasi hubungan kausal sebagai interdependensi antara fase dari perspektif driver. Penelitian selanjutnya juga dapat mengeksplorasi apakah CSF untuk sistem ERP dengan driver tata kelola TI secara positif memberi dampak pada hasil tata kelola TI (Value Delivery dan Performance Measurement). 


\subsection{Tema 3: Penerapan dan atau evaluasi tata kelola dengan berbagai metode (COBIT dan Kombinasi Metode Lainnya, konseptual model) pada sektor bisnis}

Implementasi COBIT pada perusahaan kecil kompleks dan terdapat banyak tantangan(Aguillar et al., 2017).Sehingga, integrasi dengan ISO/IEC 12207 dapat mengidentifikasi proses yang berdampak pada sasaran strategis. PDCA dan SCRUM merupakan proses perbaikan keberlanjutan. Penelian selanjutnya dapat menggunakan seperangkat kontrol dan proses dengan dampak positif di manajemen perusahaan, membantu mencapai tingkat kematangan yang lebih tinggi. COBIT untuk mengadopsi standar dan pola dalam tingkat yang disesuaikan dengan kepatuhan dan kompleksitas dalam proses, memungkinkan lebih baik proses dan pengurangan usaha/biaya

COBIT 4.1 dapat memastikan delivery dari operasi TI yang baik seperti penelitian yang dilakukan oleh (Ibrahim \& Nurpulaela, 2017) dengan studi kasus pada perusahaan (PT. Timah Tbk.). Hasil penelitiannya adalah bahwa tingkat kematangan tata kelola TI secara keseluruhan adalah saat ini diperoleh 2.88 (defined). Sedangkan, (Kosasi et al., 2017) mengimplementasikan COBIT 4.1. pada universitas swasta. Hasil yang didapatkan berdasarkan nilai yang diperoleh dengan metode COBIT 4.1 bahwa perlu spesifik tindakan manajemen diperlukan untuk mengembangkan sistem TI kesiapan dan keselarasan IT dalam pemasaran bisnis online. Perlu adanya pengukuran secara berkala nilai tingkat kematangan dengan domain lainnya untuk memastikan informasi yang jelas dan mencapai tingkat kematangan yang diharapkan. Hubungan antara kematangan proses tata kelola TI yang ada pada perusahaan diteliti oleh (Joshi et al., 2018). Berdasarkan analisis dari laporan tahun dan survei yang dilakukan pada kematangan implementasi proses COBIT 4.1. menghasilkan kerangka kerja kebijakan dari tata kelola dalam hal akuntabilitas dan transparansi. Penelitian selanjutnya dapat melakukan penelitian yang longitudinal untuk memahami hubungan antara tingkat kematangan tata kelola TI dan tingkat dari disclosure selama beberapa waktu. Kemudian, penelitian selanjutnya dapat mengukur dampak dari tingginya kematangan tata kelola TI pada nilai perusahaan. Selanjutnya juga dapat memasukkan kerangka lainnya seperti VAL IT ataupun COBIT 5.0.

Implementasi COBIT 5.0 pada perusahaan yang bergerak di bidang perkebunan sawit telah dilakukan oleh (Sandfreni \& Adikara, 2017). Hasil yang didapatkan adalah mendeskripsikan setiap tahapan untuk meningkatkan penerapan tata kelola TI, dan memberikan rekomendari tata kelola TI untuk studi kasus. Penelitian selanjutnya perlu dilakukan peningkatan proses hingga ke level 3 dengan melakukan perbaikan langkah dalam BAI04 pada studi kasus tersebut ataupun studi kasus lainnya yang juga memiliki kesamaan. Evaluasi COBIT 5.0 dilakukan oleh (Kerr \& Murthy, 2013) dengan melakukan survei kepada profesional TI. Hasil menunjukkan bahwa 5 proses yang dianggap kritis. Kemudian, penelitian ini juga menemukan pola hasil yang menarik seperti fungsi jenis pekerjaan dan lokasi geografis responden.Akan tetapi, ada kemungkinan bahwa beberapa responden tidak selaras dengan fokus pengaruh proses COBIT pada keandalan pelaporan keuangan. Sehingga, limitasi bisa mengakibatkan bias dari peringkat kepentingan.

Penelitian (Wilkin et al., 2016) menguji CGIT (PRINCE2, ITIL, COBIT, Val IT, ISO /IEC 38500) pada MSME (Micro, small, and Medium Enterprise). Hasil yang didapatkan menunjukkan secara substansial manfaat, pengaruh dan tantangan. Disamping pentinggnya penyelarasan bisnis dan TI, manajemen risiko berpengaruh signifikan kepada pengaruh keputusan untuk mengadopsi CGIT dan sebagai kunci dari peningkatan kinerja organisasi dan RBV.Dapat diteliti lebih lanjut terkait keterlibatan organisasi yang lebih kecil dengan CGIT untuk menghasilkan nilai bisnis dengan cara yang sebanding dengan rekan bisnis yang lebih besar.

Topik menarik lainnya adalah di bidang keamanan informasi. Tata kelola keamanan informasi menjadi topik yang hangat. Seperti penelitian yang dilakukan oleh (Lin \& Wittmer, 2017) tentang Proactive Information Security Behavior (PISB). Berdasarkan jawaban dari 235 responden yang berasal dari berbagai industri konseptual yang diuji mendapatkan hasil penelitian. Adanya hubungan positif dengan kreativitas individu dan budaya kelompok serta efek mediasi parsial dan penuh desentralisasi tata kelola TI dan kreativitas individu pada hubungan antara perilaku keamanan informasi proaktif danbudaya kelompok.Penelitian selanjutnya dapat menguji coba dan mengeksplorasi model konseptual pada studi kasus lainnya.Keamanan informasi dapat melengkapi tata kelola TI dalam aspek confidentiality, integrity dan availability informasi. Kerangka kerja ITG seperti ISO 27001 dan COBIT dapat digunakan untuk membantu dalam memudahkan implementasi kerangka Information Security Governance (ISG)(Fazlida \& Said, 2015). Penerapan Information Security Governance framework karena ISO 27001 dan COBIT masih terdapat celah dan limitasi dalam keamanan informasi.

Penelitian oleh (Park et al., 2017) membangun konseptual model Extended Resource-Based View(ERBV). Pengujian model konseptual dilakukan pada 213Perusahaan Korea yang telah menerapkan outsourcing IT. Hasilnya adalah Hierarchy-based alignment mengoptimalkan efisiensi operasional perusahaan, a market-based alignment dalam perkembangan pasar, dan $a$ network-based alignment mendorong untuk performance inovasi yang terbaik. Berdasarkan 
pengujian hoc terdapat beberapa keselarasan yang tidak terduga (misalnya, antara internal market dan hierarki eksternal tata kelola) yang positif mempengaruhi kinerja perusahaan, yang menjadi peluang untuk diskusi penelitian selanjutnya.

Pada bidang bisnis franchising networks, penelitian (Nuroğlu, 2016) menghasilkan konseptual model untuk menginvestigasi dampak TI pada business network, dengan variabel Transaction Costs (TCE), Resource-Based View(RBV), IT Capability. Model konspetual ini perlu di tes. Diharapkan dari tes tersebut nantinya dapat mengurangi beberapa variabel dalam variabel kapabilitas TI, RBV dan TCE.

Perusahaanyang menggunakan ERP dalam proses bisnisnya memerlukan tata kelola yang sesuai dengan arsitektur bisnis. Kerangka Kerja Tata kelola informasi yang arsiterktur Informasi terdiri dari 4 pilar dan 4 aksi diusulkan oleh (Guetat \& Dakhli, 2015) untuk perusahaan asuransi. Penelitian ini menguji usulan kerangka kerja pada arsitektur untuk tata kelola informasi. Di uji pada perusahaan asuransi yang menggunakan ERP. Kerangka kerja mendemonstrasikan tata kelola informasi tidak efektif jika dimasukkan kedalam aspek arsitektur. Penerapan prinsip arsitektur dan peraturan terkait urbanisasi sistem informasi berkontribusi terhadap efektivitas dari tata kelola informasi. Penelitian selanjutnya dapat melanjutkan validasi kerangka kerja yang diusulkan dalam konteks lain yang lebih kondusif untuk eksperimen.

Penelitian dengan menggunakan Capability Maturity Model (CMMI) yang digunakan oleh (Bermejo et al., 2014) membangun instrumen pengukuran untuk praktis tata kelola TI.Berdasarkan instrumen tersebut mengidentifikasi perbedaan profiil organisasi dalam praktis tata kelola TI, hasil bisnis, dan kematangan. Penelitian selanjutnya dapat mengaplikasikan instrumen penelitian pada negara lainnya untuk perbandingan. Karena analisis faktor menghasilkan instrumen penilaian tata kelola TI, diharapkan instrumen ini dapat diterapkan untuk mengembangkan hasil teoritis untuk model tata kelola TI. Profil yang diidentifikasi dengan analisis cluster dapat memberikan dukungan untuk merumuskan hipotesis mengenai efek praktik tata kelola TI, hipotesis yang dapat diuji selanjutnya.

Model Markov Decision Process (MDP) yang diusulkan (Thompson et al., 2014) mendukung perusahaan dalam proses pengambilan keputusan dengan melihat data yang ada dan memasukkan ekspektasi perusahaan tentang bagaimana kondisi perusahaan pada masa yang akan datang berdampak pada perubahan TI. Model ini cukup fleksibel pada berbagai jenis strategi organisasi dan struktur, dan memberikan hasil yang konsisten dengan strategi perusahaan. Limitasi model ini adalah dari segi implementasinya dan validasi eksternal.

Penelitian (Ali et al., 2015) menggabungkan kerangka kerja IT Investment Governance (ITIG) dan Val IT 2.0 dalam membangun model konseptual. Pengujian dilakukan melalui survei online berdasarkan hasil tes validitas konten dan dikelola oleh Australia berbasis vendor panel survei dikirim ke panel responden. Responden merupakan direktur, pejabat manajemen puncak dan anggota manajemen senior lainnya dalam organisasi nirlaba Australia. Hasil utama adalah empat faktor yang terdiri dari 16 item instrumen untuk mengukur konstruk ITIG, faktor tersebut adalah IT investment value governance, IT investment value monitoring, IT investment appraisals dan IT investment project management. Tedapat hubungan yang positif dan signifikan antara konstruk ITIG dan kinerja perusahaan. Perusahaan dengan level kapabilitas ITIG yang tinggi lebih memaksimalkan kontribusi investasi TI ke nilai perusahaan. Penelitian selanjutnya dapat menambahkan dimensi baru untuk instrumen ITIG. Kemudian, dapat menguji hubungan keterkaitan antara ITIG dan IT-enabled proses bisnis untuk lebih jelas mengidentifikasi bagaimana keefektifan tata kelola dari pengaruh investasi TI pada proses. Mengidentifikasi faktor sebab dan akibat yang berhubungan dengan tingkat ITIG dalam organisasi.

Konseptual model yang diuji oleh (Chi et al., 2017) dengan survei kepada 200 perusahaan berkaitan dengan hubungan antara balancing governance, complementing governance, IT ambidexterity, relational performance.Penelitian selanjutnya berdasarkan rekomendasi peneliti ini adalah penelitian selanjutnya dapat lebih menginvestigasi antecendents dari kedua strategi tata kelola. Melakukan eksplorasi kinerja perusahaan pada situasi yang berbeda dengan mengkombinasikan balancing dan complementing tata kelola. Penelitian ini mengambil data pada satu negara asia, sehingga selanjutnya dapat mengambil data dari negara lainnya. Akan menjadi lebih menarik jika menguji model pada negara yang berbeda budayanya.

Terdapat solusi yang mudah dan simpel dengan menggunakan 9 fokus area dari model kematangan sebagai sebuah kerangka kerja (Smits \& Van Hillegersberg, 2017). Menilai organisasi informal menggunakan area fokus yang sama seperti pada model kematangan tidak menambah kompleksitas dan diharapkan untuk memberikan informasi yang berguna pada konteks setiap area fokus dari Maturity IT Governance(MIG) model (Hard and soft governance). Penelitian selanjutnya dapat menguji kombinasi dari elemen kunci dan melakukan validasinya.

Menurut (Lunardi et al., 2014), perusahaan yang mengadopsi praktis tata kelola TI meningkatkan kinerjanya ketika membandingkan untuk grup kontrol, yang berhubungan dengan keuntungan. Terdapat dampak dari mekanisme adopsi tata kelola TI pada financial performance. Dari sekian banyak perusahaan yang diteliti paling 
banyak menggunakan COBIT dan ITIL.Penelitian selanjutnya dapat mengidentifikasi manfaat langsung maupun tidak langsung dengan mekanisme tata kelola yang paling banyak diadopsi oleh perusahaan tersebut. Kemudian, menunjukkan dampaknya pada proses bisnis dan keseluruhan kinerja dari perusahaan dalam lebih dari 1 tahun setelah pengimplementasian.

Model konseptual penelitian (Sirisomboonsuk et al., 2018) mencakup aspek IT Governance, Strategic Alignment, Project Governance, Project Performance. Penelitian ini berbasis survei dengan melibatkan praktisi TI atau pakar tata kelola TI di berbagai sektor. Hasil penelitian bahwa tata kelola TI dan tata kelola proyek memiliki dampak yang positif terhadap kinerja proyek. Terdapat tiga dimensi dari tata kelola TI (strategy setting, value delivery, performance management) yang secara positif berhubungan dengan kinerja proyek. Sementara ketiga dimensi dari proyek tata kelola (portfolio direction, project sponsorship as well as project effectiveness \& efficiency, dan disclosure \& reporting) secara positif berhubungan dengan kinerja proyek. Adanya keselarasan antara tata kelola TI dan tata kelola proyek berhubungan positig dengan kinerja proyek.Penelitian selanjutnya dapat menggunakan model konseptual ini pada sampel data yang lebih besar dan menggunakan responden dari negara lainnya agar mendapatkan model yang generalisasi.

Model konseptual yang dikemukakan oleh (Bin-Abbas \& Bakry, 2014) disebut dengan STOPE: Strategy, Technology, Organization, People and Environment. Hasil yang diperoleh bahwa prinsip manajemen pengetahuan sebagai penambahan nilai, dan fase dari six-sigma sebagai siklus proses peningkatan. Pengaplikasian dari pendekatan telah dipresentasikan untuk mengilustrasikan penggunaan model ini. Walaupun pendekatan STOPE merupakan kontrol utama yang berhubungan dengan dasar kebutuhan tata kelola TI, perlu diperhatikan fleksibelitas dalam merespon kebutuhan individu dan menambahkan sejumlah elemen kontrol yang diperlukan.

\subsection{Tema 4: Tata Kelola TI Pada Universitas}

Penelitian yang dilakukan oleh (Kosasi, 2017), mengimplementasikan COBIT 4.1. pada universitas swasta. Pengukuran dengan domain lainnya yang mengindikasikan hubungan yang kuat dalam seluruh domain. Kesuksesan implementasi tata kelola pada universitas swasta untuk kebutuhan internal dan eksternal perlu dibahas. Melibatkan responden dari komunitas eksternal dan menggunakan skala likerts. Dari perspektif global, poin-poin penting yang perlu diperhatikan sebelum menerapkan tata kelola TI pada tingkat universitas telah diilustrasikan oleh (Jairak et al., 2015) dengan balanced scorecard metrics dan importance-performance analysis.Begitu juga dari perspektif regional, dihasilkan panduan strategi tata kelola TI untuk universitas Thailand.Berdasarkan hasil ulasan literatur terkait perspektif tata kelola global dan panduan praktis dari survey regional dapat dikombinasikan sebagai kerangka tata kelola yang fleksibel untuk universitas thailand.

Praktis tata kelola TI berdasarkanSufficiency Economy Philosophy (SEP) untuk universitas Thailand dan pemetaan praktis tata kelola TI berdasarkan SEP dengan ISO/IEC 38500(Jairak \& Praneetpolgrang, 2013).Keterbatasan penelitian ini menyesuaikan sesuai dengan karakteristik dari universitas Thailand, sehingga penelitian selanjutnya dapat mengimplementasikan pada organisasi yang berbeda dengan menginvestigasi lebih pada panduan aplikasi yang cocok dengan studi kasus. Membuktikan regulasi yang diusulkan dampaknya bagaimana pada organisasi.

Penelitian selanjutnya adalah mengevaluasi impelementasi tata kelola TI pada universitas dengan aspek yang diperhatikan berdasarkan ISO/IEC 38500, Bussiness/IT Alignment melalui Project Portfolio Approval Process (Juiz et al., 2012). Implementasi tidak hanya membantu dalam meningkatkan komunikasi antara otoritas universitas (board) dengan staff TI, tetapi juga menyelaraskan strategi dan tujuan taktis dengan kebutuhan unit bisnis untuk proyek TI. Penelitian selanjutnya dapat memvalidasi proses melalui survei kepada stakeholder dan tingkat kepuasan dengan proyek yang dipilih. Kemudian melakukan evaluasi terhadap proyek yang dieksekusi. kerangka kerja yang diusulkan perlu dilengkapi untuk keberlanjutan peningkatan transparansi tata kelola. dengan melihat berbagai standar.

Struktur IT Governance (sentralisasi, desentralisasi, dan federal) pada universitas dieksplorasi oleh (Bianchi et al., 2017). Struktur sentralisasi memungkinkan adanya penghematan pada keterampilan dan aplikasi, sehingga pengurangan biaya dan standarisasi. Sementara struktur desentralisasi membutuhkan lebih banyak sumber daya, lebih tinggi risiko dan kesulitan dalam komunikasi di fakultas. Struktur federal lebih cocok untuk universitas karena infrastruktur dan strategi terpusat dan pelaksanaan dan operasi terdesentralisasi.Pengumpulan data terbatas pada enam universitas dan hanya satu orang (key person) yang diwawancarai dari masing-masing universitas. Selanjutnya dapat mengumpulkan data dari lebih banyak universitas untuk meningkatkan pemahaman tentang struktur tata kelola TI yang diadopsi untuk meningkatkan dan memperkuat hasil dari rangkaian penelitian ini.

\subsection{Peran Tata Kelola TI dalam Pemerintah dan Rumah Sakit (publik)}

Penggabungan ITIL V3 dan COBIT 5 dalam tata kelola dilakukan oleh (Ekanata \& Girsang, 2015), (Shalannanda \& Hakimi, 2016). Pada bidang 
pemerintahan yaitu pusat komputer kementerian departemen luar negeri di indonesia. Hasil analisis kondisi 26 proses dalam siklus ITIL dan pengukuran tingkat capability dari 18 Proses TI dalam COBIT dan hubungannya dengan layanan TI. Memberikan rekomendasi KPI(Ekanata \& Girsang, 2015). Sedangkan (Shalannanda \& Hakimi, 2016), menguji kombinasi dari kedua metode tersebut pada rumah sakit. Hasil menunjukkan beberapa deliverable yang seharusnya digunakan sebagaidasar-dasar jika Tata Kelola TI dalam suatu organisasi, seperti: Kerangka Kerja Tata Kelola TI, Struktur Organisasi TI, Struktur Tata Kelola TI, dan Koordinator Tata Kelola Sistem Informasi. Peluang penelitian selanjutnya dapat menguji coba dan mengeksplorasi model konseptual pada studi kasus lainnya.

Sedangkan penelitian (Lapihu \& Isnanto, 2017), menggunakan COBIT 5.0, ITBSC pada studi kasus di pemerintahan Kotamadya Kupang. Hasil menunjukkan bahwa tingkat kematangan Kotamadya Kupang berada di posisi 0 (proses tidak lengkap) dengan target tingkat kematangan 3 . Sehingga, Tata kelola TI kotamadya Kupang tidak dalam kondisi maksimal untuk menanggapi bisnis proses. Peneltiian selanjutnya dapat membuat rencana strategi kontekstual dari implementasi tata kelola TI.

\section{KESIMPULAN DAN SARAN PENELITIAN}

Tata kelola TI telah menjadi topik yang menarik karena pentingnya peran tata kelola TI tersebut dalam sebuah organisasi. Ketertarikan organisasi ataupun perusahaan terhadap tata kelola TI semakin berkembang karena telah berubahnya peran dan relevansi TI dalam organisasi. Terdapat 34 paper yang menjadi acuan untuk ulasan literatur ini.Penelitian yang berbasis survey atau kuisioner lebih banyak dan pembahasan tata kelola TI secara luas diterapkan pada organisasi bisnis. Berdasarkan metode ataupun konseptual model yang dikembangkan dari topik penelitian tata kelola TI menggunakan berbagai macam metode dan kombinasi dari beberapa metode. Paling banyak ditemukan penggunaan metode COBIT. Selain itu, metode kombinasi antara COBIT, ITIL, ITBSC, SCRUM, VAL IT, dan sebagainya.

Dari 34 paper tersebut disintesis menjadi 5 penelitian yaitu cloud computing governance, criteria success factor IT governance, penerapan dan atau evaluasi tata kelola dengan berbagai metode pada sektor bisnis, tata kelola TI pada Universitas, peran tata kelola dalam pemerintahan dan rumah sakit. Peluang penelitian direkomendasikan berdasarkan future dan limitasi dari masing-masing paper yang dibahas. Hambatan ataupun tantangan untuk penelitian di masa depan adalah pengukuran ataupun evaluasi tata kelola seharusnya dilakukan secara berkala dan berkelanjutan, sehingga membutuhkan waktu yang lama untuk mengetahui hasil implementasi tata kelola pada sebuah organisasi.

\section{DAFTAR PUSTAKA}

AGUILLAR, D. A. M., MURAKAMI, I., JUNIOR, P. M., \& JR., P. T. A. 2017. IT Governance Program and Improvements in Brazilian Small Business: Viability and Case Study, 11(1), 961-964. https://doi.org/10.15439/2017F410

ALI, S., GREEN, P., \& ROBB, A. 2015. Information technology investment governance: What is it and does it matter? International Journal of Accounting Information Systems, 18, 1-25. https://doi.org/10.1016/j.accinf.2015.04.002

ALREEMY, Z., CHANG, V., WALTERS, R., \& WILLS, G. 2016. Critical success factors (CSFs) for information technology governance (ITG). International Journal of Information Management, 36(6), 907-916. https://doi.org/10.1016/j.ijinfomgt.2016.05.01 7

BERMEJO, P. H. DE S., TONELLI, A. O., ZAMBALDE, A. L., SANTOS, P. A. DOS, \& ZUPPO, L. 2014. Evaluating IT Governance Practices and Business and IT Outcomes: A quantitative Exploratory Study in Brazilian Companies. Procedia Technology, 16, 849857.

https://doi.org/10.1016/j.protcy.2014.10.035

BIANCHI, I. S., SOUSA, R. D., PEREIRA, R., \& LUCIANO, E. 2017. IT Governance Structures in Brazilian, Dutch and Portuguese Universities. Procedia Computer Science, 121, 927-933. https://doi.org/10.1016/j.procs.2017.11.120

BIN-ABBAS, H., \& BAKRY, S. H. 2014. Assessment of IT governance in organizations: A simple integrated approach. Computers in Human Behavior, 32, 261-267. https://doi.org/10.1016/j.chb.2013.12.019

CHI, M., ZHAO, J., GEORGE, J. F., LI, Y., \& ZHAI, S. 2017. The influence of inter-firm IT governance strategies on relational performance: The moderation effect of information technology ambidexterity. International Journal of Information Management, $\quad 37(2), \quad 43-53$. https://doi.org/10.1016/j.ijinfomgt.2016.11.00 7

EKANATA, A., \& GIRSANG, A. S. 2015. Assessment of Capability Level and IT Governance Improvement Based on COBIT and ITIL Framework at Communication Center Ministry of Foreign Affairs, 2015, 1-6.

FAZLIDA, M. R., \& SAID, J. 2015. Information Security: Risk, Governance and Implementation Setback. Procedia Economics 
and Finance, 28(April), 243-248. https://doi.org/10.1016/S2212-5671(15)011065

GUETAT, S. B. A., \& DAKHLI, S. B. D. 2015. The Architecture Facet of Information Governance: The Case of Urbanized Information Systems. Procedia Computer Science, 64, 1088-1098. https://doi.org/10.1016/j.procs.2015.08.564

HARMER, G. 2013. Governance of Enterprise IT Based on COBIT 5. United Kingdom: IT Governance Publishing.

IBRAHIM, \& NURPULAELA, L. 2017. Evaluation of IT governance to support IT operation excellent based on COBIT 4.1 at the PT Timah Tbk. Proceedings - 2016 3rd International Conference on Information Technology, Computer, and Electrical Engineering, ICITACEE 2016, 336-339. https://doi.org/10.1109/ICITACEE.2016.7892 467

ISACA. 2013. COBIT 5 For Risk. ISACA.

JAIRAK, K., \& PRANEETPOLGRANG, P. 2013. Applying IT governance balanced scorecard and importance-performance analysis for providing IT governance strategy in university. Information Management \& Computer Security, 21(4), 228-249. https://doi.org/10.1108/IMCS-08-2012-0036

JAIRAK, K., PRANEETPOLGRANG, P., \& SUBSERMSRI, P. 2015. Information technology governance practices based on sufficiency economy philosophy in The Thai University Sector. Information Technology \& People, 28(1), 196-223. https://doi.org/10.1108/ITP-10-2013-0188

JOSHI, A., BOLLEN, L., HASSINK, H., DE HAES, S., \& VAN GREMBERGEN, W. 2018. Explaining IT governance disclosure through the constructs of IT governance maturity and IT strategic role. Information and Management, 55(3), 368-380. https://doi.org/10.1016/j.im.2017.09.003

JUIZ, C., GÓMEZ, M., \& BARCELÓ, M. I. 2012. Business / IT Projects Alignment through the Project Portfolio Approval Process as IT Governance Instrument. Procedia - Social and Behavioral Sciences, 65, 70-75. https://doi.org/10.1016/j.sbspro.2012.11.093

KERR, D. S., \& MURTHY, U. S. 2013. The importance of the CobiT framework IT processes for effective internal control over financial reporting in organizations: An international survey. Information and Management, 50(7), 590-597. https://doi.org/10.1016/j.im.2013.07.012

KITCHENHAM. 2007. Guidelines for performing Systematic Literature Reviews in Software
Engineering.

KOSALA, D. R. 2017. Benefits to Implementing IT Governance in Higher Education, (November), $15-17$.

KOSASI, S. 2017. Maturity Levels of Academic Information Services of Higher Education Using IT Governance. 4th International COnference on New Media Studies, 56-61.

KOSASI, S., VEDYANTO, \& YULIANI, I. D. A. E. 2017. Enhancing online business marketing to expand market shares through it governance. International Conference on Electrical Engineering, Computer Science and Informatics (EECSI), 4(September), 319-323. https://doi.org/10.11591/eecsi.4.1037

LAPIHU, D., \& ISNANTO, R. R. 2017. IT Governance in Public Organization Based on ITBSC and Cobit 5. In 1st International Conference on Informatics and Computational Sciences (ICICoS) (pp. 83-88).

LI, H. J., CHANG, S. I., \& YEN, D. C. 2017. Investigating CSFs for the life cycle of ERP system from the perspective of IT governance. Computer Standards and Interfaces, 50, 269279. https://doi.org/10.1016/j.csi.2016.10.013

LIN, C., \& WITTMER, J. L. S. 2017. Proactive information security behavior and individual creativity: Effects of group culture and decentralized IT governance. 2017 IEEE International Conference on Intelligence and Security Informatics: Security and Big Data, ISI 2017, $1-6$. https://doi.org/10.1109/ISI.2017.8004865

LUNARDI, G. L., BECKER, J. L., MAÇADA, A. C. G., \& DOLCI, P. C. 2014. The impact of adopting IT governance on financial performance: An empirical analysis among Brazilian firms. International Journal of Accounting Information Systems, 15(1), 6681.

https://doi.org/10.1016/j.accinf.2013.02.001

MANGALARAJ, G., SINGH, A, \& TANEJA, A. 2014. IT Governance Frameworks and COBIT-A Literature Review. Twentieth Americas Conference on Information Systems, 1-10. https://doi.org/10.2308/jis.2009.23.1.79

NUROĞLU, H. H. 2016. Business Network Governance Structure and IT Capabilities. Procedia - Social and Behavioral Sciences, 229, $50-59$. https://doi.org/10.1016/j.sbspro.2016.07.113

PARK, J., LEE, J. N., DANIEL LEE, O. K., \& KOO, Y. 2017. Alignment between Internal and External IT Governance and Its Effects on Distinctive Firm Performance: An Extended Resource-Based View. IEEE Transactions on Engineering Management, 64(3), 351-364. https://doi.org/10.1109/TEM.2017.2678485 
PRASAD, A., \& GREEN, P. 2015. Governing cloud computing services: Reconsideration of IT governance structures. International Journal of Accounting Information Systems, 19, 45-58. https://doi.org/10.1016/j.accinf.2015.11.004

PRASAD, A., GREEN, P., \& HEALES, J. 2014. On governance structures for the cloud computing services and assessing their effectiveness. International Journal of Accounting Information Systems, 15(4), 335-356. https://doi.org/10.1016/j.accinf.2014.05.005

PUTRI, M. A., AKNURANDA, I., \& MAHMUDY, W. F. 2017. Maturity Evaluation of Information Technology Governance in PT DEF Using Cobit 5 Framework. Journal of Information Technology and Computer Science, 2(1), 19-27. https://doi.org/10.25126/jitecs.20172123

REBOLLO, O., MELLADO, D., FERNÁNDEZMEDINA, E., \& MOURATIDIS, H. 2015. Empirical evaluation of a cloud computing information security governance framework. Information and Software Technology, 58, 4457.

https://doi.org/10.1016/j.infsof.2014.10.003

SANDFRENI, \& ADIKARA, F. 2017. Capability level assessment of IT governance in PTP Mitra Ogan: COBIT 5 framework for BAI 04 process. 2017 4th International Conference on Computer Applications and Information Processing Technology (CAIPT), 1-5. https://doi.org/10.1109/CAIPT.2017.8320665

SHALANNANDA, W., \& HAKIMI, R. 2016. IT Governance Design for Hospital Management Information System. 10th International Conference on Telecommunication Systems Services and Applications (TSSA).

SIRISOMBOONSUK, P., GU, V. C., CAO, R. Q., \& BURNS, J. R. 2018. Relationships between project governance and information technology governance and their impact on project performance. International Journal of Project Management, 36(2), 287-300. https://doi.org/10.1016/j.ijproman.2017.10.003

SMITS, D., \& VAN HILLEGERSBERG, J. 2017. The development of a hard and soft IT governance assessment instrument. Procedia Computer Science, 121, 47-54. https://doi.org/10.1016/j.procs.2017.11.008

SPREMIC, M., \& D, P. 2008. Emerging issues in IT Governance: implementing the corporate IT risks management model. Wseas Transactions On Systems, 7(3), 219-228.

SUICIMEZOV, N., \& GEORGESCU, M. R. 2014. IT Governance in Cloud. Procedia Economics and Finance, 15(14), 830-835. https://doi.org/10.1016/S2212-5671(14)005310
THOMPSON, S., EKMAN, P., SELBY, D., \& WHITAKER, J. 2014. A model to support IT infrastructure planning and the allocation of IT governance authority. Decision Support Systems, 59(1), 108-118. https://doi.org/10.1016/j.dss.2013.10.010

WIJAYA, S. F. 2017. Impact of IT governance framework in post- implementation for ERP performance: Literature Review. The International Conference on ICT for Smart Society (ICISS). https://doi.org/978-1-53862330-5

WILKIN, C. L., \& CHENHALL, R. H. 2010. A Review of IT Governance: A Taxonomy to Inform Accounting Information Systems. Journal of Information Systems, 24(2), 107146. https://doi.org/10.2308/jis.2010.24.2.107

WILKIN, C. L., COUCHMAN, P. K., SOHAL, A., \& ZUTSHI, A. 2016. Exploring differences between smaller and large organizations' corporate governance of information technology. International Journal of Accounting Information Systems, 22, 6-25. https://doi.org/10.1016/j.accinf.2016.07.002

YUDATAMA, U., NAZIEF, B. A. A., HIDAYANTO, A. N., \& MISHBAH, M. 2017. Factors Affecting Awareness and Attitude of IT Governance Implementation in The Higher Education Institution: A Literature Review. In 3rd International Conference on Science in Information Technology (ICSITech) (pp. 588-592).

YUDATAMA, U., NAZIEF, B. A. A., \& HODAYANTO, A. N. 2017. Benefits and Barriers as a Critical Success Factor in the Implementation of IT Governance : Literature Review. In The International Conference on ICT for Smart Society (ICISS). 